\title{
religion

\section{Will Pussy Riot Dance on \#Euromaidan? New Dissidence, Civic Disobedience and Cyber-Mythology in the Post-Soviet Context}

\author{
NATALiYA TChERMALYKH*
}

\begin{abstract}
Written in the beginning of December 2013, this article was inspired by two events that temporarily coincided: the massive manifestations in Kiyv's Maidan Square, called 'Euromaidan' and the release of Pussy Riot from prison in Russia. Asking myself if those two events were pure coincidence, or if there were a certain political or at least media causality between the two, I try to analyse both processes (Euromaidan media representation and Pussy Riot media plot) as new myths (referring to Barthes, McLuhan and Meletinskii's theories) of political resistance in post-Soviet territories, created through the media.
\end{abstract}

\section{Keywords}

Pussy Riot; cyber-activism; media activism; media and mythology; censorship.

\section{Author affiliation}

Nataliya Tchermalykh was born in 1984 in Kiev. She is a Ukrainian feminist writer and curator, co-founder and co-editor of ProStory Magazine (Ukraine). She writes about Ukrainian and post-Soviet feminism, political art and censorship.

On 9 December 2013 Russian mainstream media spread the news about President Putin's decision to grant amnesty to some prisoners convicted of political offences, a decision he publicly dedicated to the twentieth anniversary of the Russian Constitution. Under this particular act of amnesty, it was stated that 
the following individuals will soon be released from custody: Maria Alyokhina and Nadezhda Tolokonnikova, members of the music band Pussy Riot; seven prisoners of conscience from the 'Bolotnaya Case' concerning organisers of mass protests against Putin's re-election in March 2012; and activists from Green Peace who have become, among others, central figures in the youth-based antiPutin movement that has swept Russia over the past few years. Coincidentally, in the capital city of Kiev, Monday 9 December would also become emblazoned in history as international presses reported on the previous weekend and the outbreak of '\#Euromaidan', the largest popular demonstration on the territory of Ukraine to date, having brought together more than 1 million protesters dissatisfied with President Yanukovych.

Did Putin accomplish an about-face? Is his decision to modify actions taken on behalf of the Russian court system just a coincidence, or an apt framing of civil dissent in Kiev? At the time of writing this article, the political reality in Ukraine changes almost hourly and any direct connection between these events is difficult to ascertain. But the fact remains that, for now, these two closely linked events both fit into an emerging symbolic order defined by resistance to authoritarianism that is swiftly becoming characteristic in formerly Soviet spaces. What has become most clear about the situation, however, is that Ukrainian society has entered a transformative phase. All events that precede, spin off from, or simply follow '\#Euromaidan' are acquiring, through mass media venues (but not only there) a mythological, if not sacral, dimension. Where at first sight one only sees an explosion of images, texts and stagings of revolution, a closer analysis shows that several competing (and therefore ambivalent) democratisation processes spiral out from a new, national mythmaking contingent upon information technology. The least of these national myths are given over to religion.

Examining Myth and Media as a dyad can bring us closer to understanding how, today, the imaginative performances, foibles and stunts which spring from the odd juggernaut of online information largely determine several more serious concerns for average Ukrainians and Russians. My line of thinking here grows out of Roland Barthes (1975) and other modern reflections on mythmaking by Marshall McLuhan (1959) where he predicted (as early as 1959!) that new myths would spread through what he named 'electronic media'. McLuhan's view dovetails with Benedict Anderson's notion of imagined community (Anderson 1991), and both have been key to later sociological analyses on the gender and postcolonial dimensions of individual identifications with national culture (that is Nira Yuval-Davis 1997). At the same time, these authors only analysed and isolated stable socio-political structures underlying traditional societies. These inquiries also remained the level of the collective consciousness, which although it dialectically constructs and determines individual gender identities, also limits analysis when taken as an unchanging context. Transformation within the models these authors worked with has since been observed in the emergence of new, hybrid forms of gender-based resistance to traditional discourses that do not fit previously schematic interpretations of state versus society or individual versus collective. Concerning gender dissidence within contemporary Russian politics, Pussy Riot has served an active role in transforming public opinion by embodying - quite literally - a sign system that is unprecedented in post-Soviet politics. In a certain sense, we can say that these three women - not being totally led, though certainly surrounded by the international mass media - are taking their own lead in constructing a new myth of post-Soviet dissidence. 
Some performances by FEMEN unleashed similar potential, though the group could be measured as the opposite of Pussy Riot when it comes to popularity among international audiences. FEMEN created a new resistance technique $-a$ form of individual radical performance that allowed channelling their political slogans (but also the images of their bodies) through numerous paper and electronic pages of media, first on the national level, despite different forms of censorship, and then going international. This technique, later exported and translated in different ways by activist all around the world, consisted of occupying spaces of state/power importance (FEMEN's first performances took place on the Maidan square and Khreshchatik street, on the bell-tower of Sofiyska cathedral in Kyiv and later inside the Notre-Dame in Paris) and performing there an action with a high visual potential. We could call it radical contextual and aesthetic rupture: an unexpected presence of a naked female body, bearing political slogans, in a public space. Not unexpectedly, the media interest was high. Today, maybe it is already possible to admit that the mass demonstrations on Kiev's Independence Square are, or will, continue these earlier feminist demonstrations in the new patterns of symbolic resistance that are bound to follow in their wake. As in FEMEN's case, during 'Euromaidan' protests, a contextual rupture occurred, but it was from another kind, that has more to do with the representation of a Post-Soviet politics than the aesthetics. The presence of a million strong demonstration that evolved first into a sit-in, and then a live-inthe-Square protest appeared enormous and exaggerated in comparison with the inconspicuous change of external politics, voluntarily made by the former president Yanukovych, while withdrawing the EU association.

One could argue that the visual dimensions of the two - the female rebellion, put on stage by FEMEN, as well as the civic one, that took place on Maidan, both complement a (Western) visual myth of civil disobedience, that implies both a female figure, whose voice and commitment are expressed by her naked body (such as Marianne by Eugene Delacroix, a multi-layered gendered symbol of French revolution), but also the image of a stubborn crowd, that communicates with power by the language of fire and barricades, and will not dissimulate before her demands are fulfilled.

Roland Barthes designated the 'contemporary world as a privileged field for mythologisation' (Barthes 1975). Eleazar Meletinskii, a famous Soviet anthropologist, undeservingly unrenowned in the West - who conceptualised the notion of syncretism of myth and ritual as two emanations of the same essence - responded to Roland Barthes' vision in one of his last texts, and summarises post-Soviet culture vis-à-vis a more globalised comeback of religious thinking in its most archaic forms. He locates this comeback on the personal level, as well as in the public sphere, and explains the return of religious ritual as the natural outcome of the highly mechanised culture of the late Soviet era, designating this process as a 'new mythological turn' (Meletinskii 2001).

Since 1990 Russian conceptual artists, and more recently, political activists have attempted to critically reintroduce the notion of the sacred into numerous artworks. For example: the orchestrated intrusions into the Elahov Cathedral made by Aleksandr Brenner in 1995 in which the artist ran into the sanctuary during a liturgy, yelling 'Chechnya!'; the destruction of icons by Avdei TerOganyan throughout the 'Art-manege' exhibition on 4 December 1998; and the self-crucifixion performed by Oleg Mavromatti in front of the Christ the Saviour Cathedral on 1 April 2000. After the prosecution case of Yurii Samodurov 
and Andrei Erofeev, the curators of the 'Caution Religion!' exhibition at the Sakharov Museum that opened in Moscow in March 2003, the exploitation of religious themes ground to a halt. This outcome was due to high fines imposed upon the 'Caution Religion!' organisers, and the forceful emigration of Mavromatti and Ter-Oganyan.

After 2010, primary attention in political activist circles within Western media was given to FEMEN, the Ukrainian feminist group, who, though they did not define themselves as artists, organised several performances in front of cathedrals in Ukraine, Western Europe and Russia, including a series in front of the Christ the Saviour Cathedral staged in Moscow on 9 December 2011. In 2012, the punk performance group Pussy Riot managed to produce a similar, symbolically rich event in which members combined several distinct aesthetic elements employed by their Russian and Ukrainian predecessors: the re-appropriation and subversive use of traditional Christian iconography, an ironic over-identification with prayer, the transgression of gendered norms dictated by the sacred space of personal appearance (expressed in their colourful clothes and balaclavas), behaviour (abrupt gestures) and emotional prescriptions (insolence instead of humility). All of these effects combined to elicit a provocative intrusion inside the Church, a sufficiently national, as well as divine, ideologically marked physical space.

Following Meletinskii's logic, the uniqueness of the Pussy Riot performance consisted in opposing the semiotics of the highly codified orthodox ritual with a ritual of another kind, an improvised punk concert, which might have appeared totally incoherent during a 24-second viewing of it in real-time inside the Cathedral. However, in digital format, this particular action produced a virtual intrusion into the nation that appeared more real than the real. By making so visible the very essence of cyber-media, the experimental politics driving Pussy Riot's act were the first to demonstrate to the authorities the mobilisation capacities of cyber-media activism as beyond national boundaries.

It should also be noted that transformative and hybridising processes permeate within the media as well, largely due to the increasingly polylogical nature provided by the very structure of the cyber-media space. In other words, Pussy Riot's performance, or rather, the whole of Pussy Riot's case, is a storytelling of democracy that has created several displacements in Russian public discourse: first, their stage characters supplied the Russian public with a renewed figure of young girls who had not yet acquired the knowledge of the enfant-terrible of the avant-garde artists which came before them (David Ter-Oganyan or Oleg Mavromatti). Secondly, the act evaded being converted into either material or symbolic capital, unlike the glamorous multi-millionaire Mikhail Hodorkovskii, still imprisoned by 2013, or the scandalously famous writer, Eduard Limonov, who spent more than 5 years in prison. These disruptions in discourse were also an epistemological rupture, borrowing Bachelard's (1938) term, and constituted what might be thought of as a feminist achievement: Pussy Riot managed to feminise not only the activist art-scene, but also the face of contemporary Russian resistance.

As opposed to many analyses of Pussy Riot, I am reticent to sever Pussy Riot's eloquent bodies from the notion of the spaces in which they have appeared, arguing that the tension between their bodies, on the one hand, and the sacred, civil court, and jail cells in which they have appeared, on the other hand, are at the origin of Pussy Riot's mythology. It goes without mentioning that 
their bodies, dissociated from their spaces and voices, were largely depoliticised, objectified and consequently presented as 'poster beauties', 'punk rebels', or, more analytically, as 'fractional money' between different political agents on the contemporary Russian scene, or, as Anya Bernstein (2013) argues, as a 'ritual sacrifice' in the sake of sovereignty. And yet, in the media web surrounding Pussy Riot there is still one analytical piece missing which, in my opinion, is the most important and retains the potential to transform the mythological notion of the female victim's body as an element of symbolic exchange - the patriarchal paradigm, delineated by Claude Lévi-Strauss (1981). It is precisely the role of a speaking (female) subject which verbalises new forms of political activity that has remained absent from media pictures of Pussy Riot.

There are public moments in which members of the band Pussy Riot have appeared twice as speaking subjects: once in the hall of the Hamovnicheskii court where their well-prepared and articulated speech resonated in the first person and was broadcasted by all major Russian TV channels. The second instance was in an open hearing within the penal colony where Nadezhda Tolokonnikova and Maria Alekhina, despite their difficult situation, continued their civic protesting activities, through the act of speaking openly on the Internet.

The day following the proclamation of the amnesty on 9 December the Moscow newspaper 'New Times' published a long interview with three former female prisoners in the same Mordova camp where Pussy Riot was detained alongside the 29-year-old Kira Sagaidarova and Irina Noskova and 32-year-old Irina Darykina, all convicted for theft or drug possession (New Times, 2012). Some of them in the article speak about brutal beatings in prison (one of the leaders keeps boxing gloves hidden in the closet), the numerous deaths of HIVinfected women, suicides and threats 'to plant heroin' if one is approaching freedom. In an interview with these three women, each named the names of their perpetrators within the prison and thanked Nadezhda Tolokonnikova for her bravery. Previously, Evgeniya Khasis, a young far-right activist serving a 15 year term of imprisonment in the same colony as Tolokonnikova for participation in the double-murder of Baburova, and Markelov, a Russian oppositional journalist and lawyer, made a statement against Tolokonnikova, arguing that 'Tolokno is leaving by the laws of virtual reality' laws which are 'not compatible with the reality of the camp'. But in the words of Sagaidarova, Noskova and Darykina the camp and the virtual world are far from being incompatible - on the contrary, they are tightly connected. Unlike Evgeniya Khasis, they did not see in the figure of Nadezhda Tolokonnikova either a political opponent, or a 'Moscow kid-glove' nor even a punk star. She was just one of many women prisoners, which, unlike themselves, could leverage public opinion through her access to the media in order to attempt to create social change from within the prison itself. Kira Sagaidarova's assessment of the situation verges upon admiration,

In fact, the prison administration is afraid of glasnost, and for some time after such public complaints, like Tolokonnikova's letter, employees will stop their tricks, beatings, and put aside their boxing gloves. Nadia, I think, might have missed a few things, but still, we have plenty more to say.

Surprisingly enough, in Kira Sagaiadova's speech there appears a half-forgotten word - 'glasnost' - that once overwhelmingly determined the available lexicon of Soviet dissidents' vocabulary, though in Russia today the recovery of this 
word by their descendants is less and less audible, due to harsh attacks on the freedom of speech.

In an article I wrote in August 2012, when the whole globe seemed to follow the hysteria around Pussy Riot in the media as if it were an abstract saga, I viewed the archaic dimension of the same media debate in which bloodthirsty and vicious 'evil' characterisations were contrasted by tender and young 'good' saintly depictions of the situation (Tchermalykh 2012). This opposition seemed to be fuelled from all sides, while my attempts to deconstruct the fairy-tale elements of the story were in the minority: 'According to the laws of the genre, any defeat of the force of good is temporary: "princesses" are thrown into prison, but on the horizon sooner or later there will appear a Saviour while the evil embodied in an authoritarian regime will be necessarily defeated'. Whether the tale will play out so in real politics, time will tell, I wrote then, though, most importantly, I asked: "Who will be this ghostly "betrothed"? This is, as they say, another story. But the whole world seems to be waiting ...'. The waiting took a year and a half. Today, this hero, de facto, appeared to be Vladimir Putin in person, who signed the order for amnesty with his right hand, while with his left, he secured the status quo of an evil genius: the amnesty occurred only six months before the official deadline for their release. Nevertheless, as a Ukrainian feminist, I would like to believe my civil freedom grows out of a better myth than fairy-tale coincidences. 8 December: over a million people unite across divided parties for civic freedom on Kiev's Independence Square. 9 December: political activists are amnestied in Russia. Is it possible that the civil society in Ukraine has participated in liberating prisoners of conscience? In believing that power is transmitted through voice and story, quite possibly, I, too, am creating new myths, however democratic and feminist they may be.

\section{References}

Anderson, B.R.O'G. 1991. Imagined Communities: Reflections on the Origin and Spread of Nationalism (revised and extended ed.), London: Verso.

Bachelard, G. 1938. La Formation de l'esprit scientifique, Paris: Librairie philosophique J. Vrin.

Barthes, R. 1975. Le myth aujourd'hui in Mythologies, Paris: Editions de Seuil.

Bernstein, A. 2013. 'An Inadvertent Sacrifice: Body Politics and Sovereign Power in the Pussy Riot Affair', Critical Inquiry [online], accessed 19 November 2013, http:// criticalinquiry.uchicago.edu/an_inadvertent_sacrifice_body_politics_and_sovereign_ power_in_the_pussy_rio/.

Lévi-Strauss, Claude. 1981. Les structures élémentaires de la parenté. Paris; La Haye: Mouton et Co.

McLuhan, M. 1959. 'Myth and Mass Media', Daedalus 88:2, 339-348.

Meletinskii, E. 2001. Dvadtsatyi vek $i$ mif, accessed 19 November 2013, http://www. ruthenia.ru/folklore/meletinsky1.htm.

Tchermalykh, N. 2012. 'On the wave of Pussy Riot', Polityczna Krytyka (Ukraine) 4: 15-19.

Yuval-Davis N. 1997. Gender \& Nation, London: Sage. 